\title{
The fatty acid and cholesterol composition of enriched egg yolk lipids obtained by modifying hens' diets with fish oil and flaxseed
}

\author{
By Hasan Yalçýn ${ }^{1 *}$, Mustafa Kemal Ünal ${ }^{2}$ and Hatice Basmacýoolu ${ }^{3}$ \\ ${ }^{1}$ Selçuk University, Technical Science Vocational High School, Food Technology Department, \\ Konya, Turkey \\ hsnyalcin@ hotmail.com - Fax:+903322410185 - Tel:+903322232368 \\ 2 Ege University Engineering Faculty, Food Engineering Dep., Izmir, Turkey \\ ${ }^{3}$ Ege University Agricultural Faculty, Izmir, Turkey \\ ${ }^{*}$ Correspondence addresses
}

\section{RESUMEN}

Composición en ácidos grasos y colesterol de los lípidos de yema de huevo enriquecida mediante modificación de la dieta de gallinas con aceite de pescado y linaza.

Se han estudiado los efectos producidos por la presencia de aceite de pescado y linaza, en la dieta de gallinas ponedoras, sobre la composición en colesterol y ácidos grasos de los lípidos del huevo. Se han utilizado gallinas ponedoras Isa-White y cinco tipos de dietas experimentales. La primera dieta fue usada como control. Se añadió aceite de pescado $(1.5 \%)$, linaza $(4.32 \%$ y 8.64$)$ o ambos $(1.5 \%$ aceite de pescado y $4.32 \%$ linaza) a las otras dietas y se alimentó a las gallinas durante 30 y 60 días, determinándose la composición en colesterol y ácidos grasos de las yemas. No se encontró diferencia significativa $(p<0.05)$ debida a las dietas en el contenido de colesterol de las yemas excepto en la que contenía $8.64 \%$ de linaza. El contenido total de ácidos grasos saturados disminuyó en todas las dietas en comparación con la dieta control. El contenido total de ácidos grasos n-3 fue significativamente mayor en todas las dietas. El cambio predominante en las dietas que contenían linaza se encontró en el contenido de ácido linolénico. El contenido de los ácidos eicosapentaenoico, docosapentaenoico y docosahexaenoico de todas las dietas fue significativamente mayor.

PALABRAS-CLAVE: Aceite de pescado - Ácido graso Colesterol - Huevo - Linaza - Omega 3.

\section{SUMMARY}

The fatty acid and cholesterol composition of enriched egg yolk lipids obtained by modifying hens' diets with fish oil and flaxseed.

The effects of fish oil and flaxseed in the diets of laying hens on the cholesterol and fatty acid composition of egg lipids were studied. Isa-White laying hens and five experimental diets were used. The first diet was used as the control. Fish oil $(1.5 \%)$, flaxseed $(4.32 \%$ and 8.64$)$ or both of them $(1.5 \%$ fish oil and $4.32 \%$ flaxseed) were added to the others and hens were fed for 30 and 60 days. The cholesterol and fatty acid composition of the yolks were determined. No significant difference $(p<0.05)$ was found in the cholesterol content of the yolks due to diets except the diet containing $8.64 \%$ flaxseed. Total saturated fatty acid content was decreased in all diets compared to the control diet. Total n-3 fatty acid content was significantly greater for all diets. The predominant change in flaxseed containing diets was found in linolenic acid content.
Eicosapentaenoic acid, docosapentaenoic acid and docosahexaenoic acid content of all diets was significantly greater.

KEY-WORDS: Cholesterol - Egg- - Fatty acid - Fish oil - Flaxseed - Omega 3.

\section{INTRODUCTION}

It is well recognized that most so-called lifestyle diseases of high risk in the world, especially in western societies, particularly in Turkey, arise from common dietary errors. This is evident in the excess of fat, and perhaps even more important, its unfavourable composition in the diet. But there has been increasing public demand for fat and cholesterol-modified products for two decades. Recent recommendations by health professionals call for foods which are low in cholesterol and high in polyunsaturated fatty acids (PUFA) and therefore are healthier.

There is growing consensus among nutritionists that dietary PUFA of the $n-3$ series play an important role in human health (Kinsella, et al., 1990). Many studies and clinical investigations have proven that n-3 PUFA, particularly eicosapentaenoic acid (EPA) and docosahexaenoic acid (DHA) exert beneficial effects on human health. n-3 fatty acids are essential for normal growth and development and demonstrate serum lipid lowering, antithrombotic, antiarrythmic, and anti-inflammatory effects ( $\mathrm{Hu}$ et al., 1999 ; Li et al., 1999). Dietary intake of n-3 PUFA provides an inhibitory effect on the growth of prostate and breast cancer (Pandalai et al., 1996) and delays the loss of immunological functions (Fernandez, 1995).

Daviglus et al. (1997), reported that the risk of heart attack is decreased by $50 \%$ in populations that consume six or more servings of fish each month. The main dietary source of DHA and EPA is fish oil. Although fish oil is considered to be the primary source of n-3 PUFA, it may not serve as a primary source for people in certain parts of the world (Lewis et al., 2000). Unfortunately, the intake 
of fish oil in the western diet is usually low, which precipitates health problems for the whole population. Seasonal availability, cost, distance from sea of location and consumer preference may limit fish consumption. Also, certain population groups who have specific needs for n-3 PUFA (e.g. pregnant women, children) are at greater risk of $n$ 3 PUFA deficiency.

Flaxseed is a rich plant source of alpha-linolenic acid (ALA). ALA is an essential fatty acid in the human diet and the parent fatty acid of the n-3 family. ALA is converted into two main long chain fatty acids, EPA and DHA in a series of enzymatic reactions. Linoleic acid (LA) is the parent compound of the n-6 family; arachidonic acid (AA) is the metabolic of the LA. This two-parent fatty acid requires the same saturation enzyme, $\Delta-6$ desaturase. This same requirement for the desaturation of two fatty acids resulted in competition between them. An excess of one family of fatty acids can interfere with the metabolism of the other (Tapiero et al., 2002). Dietary enrichment with flaxseed may result in an excess of ALA, which is a precursor of DHA and EPA in the human body. Therefore it can be substituted for fish oil.

A good way to raise the n-3 PUFA content in the diet, without radical changes in eating habits, seems to be the enrichment of frequently consumed food products. The consumption of eggs in Turkey in 2003 was almost 13 billion (Anon, 2005), which is approximately four eggs per person per week. But the industrial production of hens includes feeds which are rich in grains containing $n$ 6 fatty acids, leading to the production of eggs rich in $n-6$ and poor in $n-3$ fatty acids (Simopoulos, 2000). This has led to a recent interest in feeding laying hens with sources rich in long chain n-3 fatty acids in order to produce eggs with higher levels of n-3. n-3 PUFA-enriched eggs may provide a dietary source of n-3 PUFA, particularly for persons who do not include fish in their diets and who like egg e.g. children. Three n-3 PUFA enriched eggs provide approximately the same amount of n-3 PUFA as a meal with fish (Lewis et al., 2000). Egg can, therefore, be an alternative to fish and oilseeds as a source of $n-3$ fatty acids. Furthermore enriched eggs can be used in the food industry for processed food products, for example in a bakery. A wide range of processed foods enriched with n-3 fatty acids would make it is easier for people to increase the amount of PUFA in the diet without special efforts.

The aim of this research was to examine the effect of fish oil and flaxseed to diets of laying hens on cholesterol and fatty acid composition of egg lipids.

\section{MATERIALS AND METHODS}

One hundred and twenty, 34 weeks of age, IsaWhite laying hens were randomly divided into five groups (24 hens per group) and placed in battery type cages at $22-24{ }^{\circ} \mathrm{C}$. The first group of laying hens was fed only standard commercial diet as a control. 1.5\% fish oil (imported menhaden oil) was added to the commercial laying diet and the second group of hens was fed this diet. $4.32 \%$ flaxseed, which is equivalent to $1.5 \%$ flaxseed oil, was added to the commercial diet and a third group of hens were fed this diet. $1.5 \%$ fish oil and $4.32 \%$ flaxseed were added to the commercial laying diet and the fourth group of hens was fed with this mixture. $8.64 \%$ flaxseed, which is equivalent to $3 \%$ flaxseed oil, was added to the commercial diet and the last group of hens was fed this diet. The diets were kept isoenergetic and supplied daily. The compositions of the diets are shown in table 1. For the determination of cholesterol and fatty acid composition six eggs from each dietary treatment were randomly selected (within replicate) from each group on the $30^{\text {th }}$ and $60^{\text {th }}$ days of the trial. The experiment was a completely randomized design with an individual hen as an experimental unit. The yolk from each egg was separated and analyzed immediately.

Lipids were extracted from the egg yolks using the standard method of Association of Official Analytical Chemists, (AOAC, 1990). According to this method $4 \mathrm{~g}$ well mixed egg yolk was weighed into a $100 \mathrm{ml}$ volumetric flask and $25 \mathrm{ml}$ chloroformabsolute alcohol were added (1:1) the solvent was mixed very slowly from pipet. It was shaken constantly until proteins were coagulated. An additional 60-65 ml mixed solvent was added and let stand for $1 \mathrm{~h}$, shaken every $5 \mathrm{~min}$. At the end of the time it was diluted to volume with mixed solvent and the mixture was let stand until clear. The mixture was then filtered very slowly (filtrate should be clear), solvent was evaporated and egg yolk lipid was obtained.

The fatty acid methyl esters were prepared from lipid extracts according to the method described by Joseph and Ackman (1992) and quantified by gasliquid chromatography (GLC). The fatty acid methyl esters were analysed using $50 \times 0.25$ inside diameter fused silica CP-Sil 88 capillary column installed on a Hewlett Packard 5890 GLC with flame ionization detector. The GLC was temperature programmed to start at $170^{\circ} \mathrm{C}$ and increase at $1{ }^{\circ} \mathrm{C} / \mathrm{min}$ to $205^{\circ} \mathrm{C}$. The injector and detector temperatures were set at $250^{\circ} \mathrm{C}$ and $270^{\circ} \mathrm{C}$ respectively. Hydrogen was used as a carrier gas at a flow rate of $1 \mathrm{ml} / \mathrm{min}$, and the split ratio was $1: 50$.

For the cholesterol analysis the AOAC (1993) method was applied with some modifications. $10 \mathrm{~g}$ egg yolk samples were transferred to a $250 \mathrm{ml}$ flask. The sample was stirred in an ethanol-methanolisopropanol (90:5:5) solution, in an amount equivalent to $4 \mathrm{ml} / \mathrm{g}$ sample, and $1 \mathrm{ml} 60 \% \mathrm{KOH} / \mathrm{g}$ sample. The flask containing the mixture was connected to the water-cooled condenser and refluxed for $1 \mathrm{hr}$. After cooling the digest to room temperature, $100 \mathrm{ml}$ of hexane were added and the mixture was stirred for $10 \mathrm{~min} .25 \mathrm{ml}$ of deionized water were added and the mixture stirred for a 
Table 1

The composition of the diets (\%)

\begin{tabular}{|c|c|c|c|c|c|}
\hline \multirow[b]{2}{*}{ Ingredient } & \multicolumn{5}{|c|}{ Dietary Groups } \\
\hline & I & II & III & IV & V \\
\hline Corn & 60.47 & 53.90 & 52.60 & 49.72 & 48.45 \\
\hline Soybean meal & 12.92 & 18.33 & 17.78 & 15.66 & 15.36 \\
\hline Cottonseed meal & 9.58 & 10.00 & 7.64 & 12.50 & 9.77 \\
\hline Bran & 0.74 & 5.65 & 8.03 & 5.97 & 8.41 \\
\hline Flaxseed & - & - & 4.32 & 4.32 & 8.64 \\
\hline Sawdust & 1.0 & 0.65 & 0.56 & 0.03 & - \\
\hline Fish oil & - & 1.5 & - & 1.5 & - \\
\hline Limestone & 6.73 & 7.83 & 6.90 & 8.00 & 7.39 \\
\hline Dicalcium phosphate & 1.69 & 1.46 & 1.41 & 1.61 & 1.31 \\
\hline Salt & 0.28 & 0.29 & 0.28 & 0.28 & 0.27 \\
\hline Mineral premix ${ }^{1}$ & 0.20 & 0.20 & 0.20 & 0.20 & 0.20 \\
\hline Vitamin premix ${ }^{2}$ & 0.10 & 0.10 & 0.10 & 0.10 & 0.10 \\
\hline Methionine & 0.08 & 0.10 & 0.10 & 0.10 & 0.10 \\
\hline \multicolumn{6}{|l|}{ Calculated Composition } \\
\hline Dry matter & 90.63 & 91.16 & 90.94 & 91.55 & 91.43 \\
\hline Crude protein & 16.49 & 16.31 & 16.41 & 16.28 & 16.60 \\
\hline Crude fat & 3.03 & 4.26 & 4.44 & 5.75 & 5.85 \\
\hline Crude fibre & 4.38 & 4.34 & 4.20 & 4.34 & 4.7 \\
\hline Crude ash & 10.89 & 11.63 & 10.88 & 12.19 & 12.69 \\
\hline Starch & 39.13 & 36.68 & 36.41 & 34.78 & 33.97 \\
\hline Metabolic Energy, kcal/kg & 2741 & 2730 & 2736 & 2765 & 2764 \\
\hline Sugar & 4.19 & 4.01 & 3.95 & 3.72 & 4.01 \\
\hline $\mathrm{Ca}$ & 3.36 & 3.906 & 3.80 & 3.87 & 3.91 \\
\hline$P$ & 0.74 & 0.72 & 0.72 & 0.77 & 0.74 \\
\hline
\end{tabular}

I: Commercial diet for control

II: Commercial diet containing $1.5 \%$ fish oil

III: Commercial diet containing $4.32 \%$ flaxseed (which means $1.5 \%$ flaxseed oil)

IV: Commercial diet containing $1.5 \%$ fish oil $+4.32 \%$ flaxseed

V: Commercial diet containing $8.64 \%$ flaxseed (which means $3 \%$ flaxseed oil)

${ }^{1}$ Mineral premix containing the following per kilogram of diet: $80 \mathrm{mg}$ manganese, $60 \mathrm{mg}$ zinc, $60 \mathrm{mg}$ iron, $5 \mathrm{mg}$ copper, $0.15 \mathrm{mg}$ selenium, $0.2 \mathrm{mg}$ cobalt, $1 \mathrm{mg}$ iodine.

${ }^{2}$ Vitamin premix containing the following per kilogram of diet: $12000 \mathrm{IU}$ Vitamin A, 2000 IU Vitamin $\mathrm{D}_{3}, 35 \mathrm{IU}$ Vitamin E, 5 mg Vitamin $\mathrm{K}_{3}, 3 \mathrm{mg}$ Vitamin $\mathrm{B}_{1}, 6$ $\mathrm{mg}$ Vitamin $\mathrm{B}_{2}, 6 \mathrm{mg}$ Calcium D-pantothenate, $5 \mathrm{mg}$ Vitamin $\mathrm{B}_{6}, 0.015 \mathrm{mg}$ Vitamin $\mathrm{B}_{12}, 0.75 \mathrm{mg}$ Folic acid, $0.045 \mathrm{mg}$ D-Biotine, $50 \mathrm{mg}$ Vitamin C, $20 \mathrm{mg}$ Niacin, $350 \mathrm{mg}$ choline chloride.

further $15 \mathrm{~min}$. The layers were then separated and the hexane layer was collected in an Erlenmeyer flask. An aliquot of $25 \mathrm{ml}$ from the hexane layer was evaporated in a rotary evaporator at $37^{\circ} \mathrm{C}$. The residue was dissolved in $2 \mathrm{ml}$ hexane and $3 \mu$ l were injected into a gas chromatography. For analysis Hewlett Packard 5890 GLC with flame ionization detector was used. Fused silica SE-30 capillary column $(25 \times 0.25$ inside diameter $)$ was installed. Column temperature was set at $260^{\circ} \mathrm{C}$. The injector and detector temperatures were set at $260^{\circ} \mathrm{C}$ and $300{ }^{\circ} \mathrm{C}$ respectively. Hydrogen was used as a carrier gas at a flow rate of $1.5 \mathrm{ml} / \mathrm{min}$, and the split ratio was $1: 150$.

Data for the cholesterol and fatty acid compositions of egg yolk were analysed by SAS (Anon, 1989). Level of significance was set at $\mathrm{p}<0.05$.

\section{RESULT AND DISCUSSION}

The fatty acid composition of the control eggs' and the n-3 enriched eggs' lipids are listed in table
2 for a 30-day feeding period and in table 3 for a 60 day feeding period. The fatty acid composition of egg yolk lipids reflected that of the laying hen diets (Table 4). However, the magnitude of change was different according to the fatty acid type. The results showed that palmitic acid was the predominant saturated fatty acid. All dietary treatment decreased palmitic acid. The reduction in the amount of palmitic acid was greater as the feeding period was longer for all feeding types. This reduction indicates an additional health advantage for these $n-3$ enriched eggs (Ayerza and Coates, 2000). The second major saturated fatty acid was stearic acid, which was not significantly influenced by dietary treatment. Miristic acid, the other saturated fatty acid existing in egg yolk lipids, composed a very small proportion of the total fatty acid content of the egg yolks. The reduction in the amount of miristic acid was only observed in flaxseed containing diets (III and V) and in feeding period. The total saturated fatty acid content was significantly decreased in flaxseed containing diets (III, IV and V) and by feeding period (Table 2 and 3 ). 
Table 2

Fatty acid composition of egg yolks of hens fed with different type of diet for 30 days feeding period (\% of total fatty acids) ${ }^{1}$

\begin{tabular}{|c|c|c|c|c|c|c|c|}
\hline & I & II & III & IV & V & $\mathrm{LSD}^{2}$ & \\
\hline $14: 0$ & $0.33^{c}$ & $0.48^{b}$ & $0.26^{d}$ & $0.53^{a}$ & $0.22^{d}$ & 0.016 & $\star \star$ \\
\hline $16: 0$ & $26.33^{a}$ & $25.80^{a b}$ & $24.13^{c}$ & $25.07^{b c}$ & $22.06^{d}$ & 0.375 & ** \\
\hline $16: 1$ & $3.19^{b}$ & $3.57^{a}$ & $3.01^{b}$ & $3.28^{a}$ & $2.65^{c}$ & 0.123 & ** \\
\hline 18:0 & $9.01^{\mathrm{a}}$ & $8.22^{b}$ & $9.05^{a}$ & $8.96^{a}$ & $9.46^{\mathrm{a}}$ & 0.199 & ** \\
\hline $18: 1$ & 38.29 & 39.30 & 37.50 & 35.54 & 37.72 & 0.863 & $\mathrm{NSD}^{3}$ \\
\hline $18: 2(n-6)$ & 17.22 & 16.24 & 18.02 & 17.74 & 17.65 & 0.665 & NSD \\
\hline $18: 3(n-3)$ & $0.62^{d}$ & $0.71^{d}$ & $3.49^{c}$ & $4.00^{b}$ & $5.89^{a}$ & 0.124 & $\star \star$ \\
\hline $18: 4(n-3)$ & $0.20^{a}$ & $0.16^{b}$ & $0.16^{b}$ & $0.13^{b}$ & $0.15^{b}$ & 0.012 & ** \\
\hline $20: 4(n-6)$ & $2.25^{a}$ & $1.13^{d}$ & $1.52^{b}$ & $0.91^{\mathrm{e}}$ & $1.36^{c}$ & 0.042 & ** \\
\hline $20: 5(n-3)$ & - & $0.18^{b}$ & $0.06^{d}$ & $0.26^{a}$ & $0.12^{c}$ & 0.009 & ** \\
\hline $22: 5(n-3)$ & $0.07^{b}$ & $0.19^{a}$ & $0.17^{a}$ & $0.21^{a}$ & $0.22^{a}$ & 0.015 & ** \\
\hline $22: 6(n-3)$ & $0.65^{d}$ & $3.29^{a}$ & $1.70^{\mathrm{c}}$ & $2.90^{b}$ & $1.98^{c}$ & 0.108 & ** \\
\hline$n-6 / n-3$ & $12.64^{\mathrm{a}}$ & $3.83^{b}$ & $3.50^{b}$ & $2.49^{c}$ & $2.27^{c}$ & 0.289 & ** \\
\hline$\sum$ SFA & $35.67^{a}$ & $34.50^{b}$ & $33.44^{c}$ & $34.56^{b}$ & $31.74^{d}$ & 0.375 & ** \\
\hline$\sum n-3$ & $1.54^{e}$ & $4.53^{d}$ & $5.58^{c}$ & $7.50^{b}$ & $8.36^{a}$ & 0.204 & ** \\
\hline$\sum n-6$ & 19.47 & 17.37 & 19.54 & 18.65 & 19.01 & 0.688 & NSD \\
\hline
\end{tabular}

1: Means of six samples. Different letters in the same line are significantly different $(p<0.05)$.

2: Least significant differences of means ( $5 \%$ level)

3: Not significantly different

There is no significant difference in oleic acid, the major monounsaturated fatty acid in egg lipids, for the first and second period. The other monounsaturated fatty acid in egg lipid is palmitoleic acid. There is only a decrease in this fatty acid amount in feeding diet $\mathrm{V}$ at two feeding periods. Baucells et al. (2000) reported that the ability of the laying hens to change the monounsaturated fatty acid content (mainly as oleic acid) in yolk seems limited. According to these fatty acid results, it can be said that the proven tendency of laying hens is to keep the degree of monounsaturation in yolk within very narrow margins.
Hargis et al. (1991) and Van Elswyk et al. (1992) reported that the linoleic acid (n-6) content was reduced in eggs through diets containing menhaden oil. But Jiang et al. (1991) and Cherian and Sim (1991) reported that linoleic acid was increased in eggs as hens' diets contained flaxseed oil. In our study there was no significant difference in the linoleic acid content in the eggs of all diet types in the first feeding period (Table 2). However, there was a significant reduction in this fatty acid amount in the eggs obtained from fish oil containing diets (II, IV) in the second feeding period (Table 3) in accordance with Hargis et al. (1991) and Van Elswyk et al. (1992). Contrary to other findings,

Table 3

Fatty acid composition of egg yolks of hens fed with different type of diet for 60 days feeding period (\% of total fatty acids)

\begin{tabular}{|c|c|c|c|c|c|c|c|}
\hline & I & II & III & IV & V & LSD $^{2}$ & \\
\hline $14: 0$ & $0.31^{b}$ & $0.48^{a}$ & $0.23^{c}$ & $0.45^{a}$ & $0.22^{c}$ & 0.013 & ** \\
\hline 16:0 & $25.92^{a}$ & $25.48^{a}$ & $23.12^{b}$ & $23.91^{b}$ & $21.33^{c}$ & 0.302 & $\star \star$ \\
\hline $16: 1$ & $2.95^{\mathrm{b}}$ & $3.47^{\mathrm{a}}$ & $3.06^{b}$ & $3.17^{b}$ & $2.50^{\mathrm{c}}$ & 0.084 & ** \\
\hline 18:0 & 9.19 & 8.92 & 8.53 & 8.68 & 9.17 & 0.197 & $\mathrm{NSD}^{3}$ \\
\hline $18: 1$ & 37.46 & 39.14 & 40.37 & 36.21 & 36.20 & 1.003 & NSD \\
\hline $18: 2(n-6)$ & $19.08^{a}$ & $16.29^{c}$ & $17.16^{\mathrm{b}}$ & $17.04^{b}$ & $19.44^{\mathrm{a}}$ & 0.581 & $\star *$ \\
\hline $18: 3(n-3)$ & $0.56^{c}$ & $0.71^{\mathrm{c}}$ & $3.23^{b}$ & $3.60^{b}$ & $6.66^{\mathrm{a}}$ & 0.180 & $\star \star$ \\
\hline $18: 4(n-3)$ & $0.21^{a}$ & $0.15^{c}$ & $0.14^{c}$ & $0.14^{c}$ & $0.18^{b}$ & 0.012 & $* *$ \\
\hline $20: 4(n-6)$ & $2.33^{a}$ & $1.30^{\mathrm{c}}$ & $1.52^{b}$ & $1.04^{d}$ & $1.40^{\mathrm{b}}$ & 0.053 & $\star *$ \\
\hline $20: 5(n-3)$ & - & $0.19^{a}$ & $0.07^{c}$ & $0.22^{a}$ & $0.13^{b}$ & 0.013 & $\star *$ \\
\hline $22: 5(n-3)$ & $0.07^{b}$ & $0.19^{a}$ & $0.22^{a}$ & $0.23^{a}$ & $0.24^{a}$ & 0.021 & ** \\
\hline $22: 6(n-3)$ & $0.63^{c}$ & $3.42^{a}$ & $1.90^{b}$ & $3.24^{\mathrm{a}}$ & $1.95^{\mathrm{b}}$ & 0.095 & ** \\
\hline$n-6 / n-3$ & $14.56^{a}$ & $3.77^{\mathrm{b}}$ & $3.36^{b}$ & $2.43^{c}$ & $2.28^{c}$ & 0.202 & ** \\
\hline$\sum$ SFA & $35.42^{a}$ & $34.88^{a}$ & $31.88^{c}$ & $33.04^{b}$ & $30.72^{d}$ & 0.384 & $\star *$ \\
\hline$\sum n-3$ & $1.47^{\mathrm{e}}$ & $4.66^{d}$ & $5.56^{c}$ & $7.43^{b}$ & $9.16^{a}$ & 0.219 & $* *$ \\
\hline$\sum n-6$ & $21.41^{a}$ & $17.58^{b}$ & $18.68^{b}$ & $18.08^{b}$ & $20.84^{a}$ & 0.595 & $\star *$ \\
\hline
\end{tabular}

1: Means of six samples

2: Least significant differences of means ( $5 \%$ level)

3: Not significantly different 
Table 4

Fatty acid composition of the diets (\% of total fatty acids)

\begin{tabular}{|c|c|c|c|c|c|}
\hline & I & II & III & IV & V \\
\hline $14: 0$ & 0.09 & 2.64 & 0.11 & 1.91 & 0.11 \\
\hline 16:0 & 10.59 & 13.32 & 9.78 & 10.39 & 8.14 \\
\hline $16: 1$ & 0.14 & 3.05 & 0.15 & 2.29 & 0.15 \\
\hline 18:0 & 2.29 & 2.94 & 3.35 & 3.29 & 3.48 \\
\hline $18: 1$ & 26.51 & 23.06 & 21.99 & 21.43 & 20.86 \\
\hline $18: 2(n-6)$ & 57.57 & 39.29 & 41.38 & 31.81 & 34.00 \\
\hline $18: 3(n-3)$ & 2.35 & 2.74 & 22.85 & 18.87 & 33.25 \\
\hline $18: 4(n-3)$ & - & 0.87 & - & 0.61 & - \\
\hline $20: 4(n-6)$ & - & 0.27 & - & 0.30 & - \\
\hline $20: 5(n-3)$ & - & 3.53 & - & 2.70 & - \\
\hline $22: 5(n-3)$ & - & 0.49 & - & 0.34 & - \\
\hline $22: 6(n-3)$ & - & 6.78 & - & 5.25 & - \\
\hline$n-6 / n-3$ & 24.50 & 2.69 & 1.81 & 1.25 & 1.02 \\
\hline$\sum \mathrm{SFA}^{1}$ & 12.97 & 18.90 & 13.24 & 15.59 & 11.73 \\
\hline$\sum n-3$ & 2.35 & 14.68 & 22.85 & 27.27 & 33.25 \\
\hline$\sum n-6$ & 57.57 & 39.56 & 41.38 & 32.11 & 34.00 \\
\hline
\end{tabular}

${ }^{1}$ Saturated Fatty Acids

Jiang et al. (1991) and Cherian and Sim (1991), there was a significant reduction in this fatty acid amount in the eggs of hens whose diet contained only flaxseed except diet $\mathrm{V}$. There was no alteration in the linoleic acid content from diet $\mathrm{V}$.

There was a significant decrease in the other $n$ 6 fatty acid, arachidonic acid $\left(\mathrm{C}_{20: 4}\right)$, with all types of diet in the second feeding period (Table 2-3). This reduction of $n-6$ fatty acids is important for the ratio of the $n-6$ to $n-3$ fatty acids. In this ratio $n-3$ fatty acids play an important role. The major changes in the fatty acids through dietary flaxseed and fish oil can be summarized as an increase in $n-3$ PUFA. The results showed that $n-3$ PUFA increased in the egg yolk lipids with an increasing amount of flaxseed or fish oil in the diet.

The amount of ALA in the eggs obtained from hens with flaxseed containing diets (III, IV, V) significantly increased compared to the control eggs (I). Feeding with diet $\mathrm{V}$ resulted in the highest ALA content in egg yolk with the all diets. A rise in flaxseed in the diet resulted in increases in ALA concentration in the yolk lipids. Hence the rise in total n-3 fatty acids in eggs obtained from hens' flaxseed containing diets can be explained mainly because of an important increase in ALA concentration in the yolk lipids. There is no alteration in the ALA of eggs from diets containing fish oil alone. But eggs from the fish oil and flaxseed mixture containing diet have higher ALA content than eggs from a diet containing the same amount of flaxseed alone.

Other n-3 fatty acids found in dietary eggs are eicosapentaenoic acid (EPA), docosapentaenoic acid (DPA) and docosahexaenoic acid (DHA). It has been shown that control eggs do not contain EPA, but contain a little amount DPA and DHA (Table 2, 3 ). The second diet (II) has a lower EPA amount than the fourth diet. Whereas both diets contain the same amount of fish oil, the fourth diet contains $1.5 \%$ flaxseed oil. Moreover although there is not any EPA composition in diet III or diet V, eggs obtained from these diets contained EPA. The eggs obtained from diet $\mathrm{V}$ (containing twice the amount of flaxseed as diet III) (Table 1) have twice as much EPA as the eggs obtained from diet III in the first period.

Flaxseed oil does not contain EPA or DHA, but it contains a large amount of ALA, which is a precursor of EPA, DPA and DHA. It is the same as the two n-3 fatty acids, DPA and DHA. Although the third and fifth diets do not contain DPA or DHA, these fatty acids exist in egg yolk lipids obtained from hens fed by those diets. EPA, DPA and DHA are obtained in eggs from a double path; on the one hand, because of the direct deposit of these fatty acids from the diet (e.g. fish oil), on the other, as a result of the synthesis from its precursors (ALA) given in the diet.

Fish oil used in hens' diets is rich in EPA and DHA (Table 5) and flaxseed used in hens' diets is rich in ALA (Table 5). Therefore the double path of the EPA and DHA deposit can be seen in this study. According to the fatty acid composition of the diets (Table 4) there is not a proportional increase in the amount of EPA, DPA and DHA. Although EPA compositions in diets II and IV are higher than the DPA composition of these diets, the DPA composition of eggs obtained from these diets is higher than the EPA composition. During the conversion of ALA, EPA, DPA and DHA appear as a long chain metabolite. DPA occupies an intermediate position in the interconversion of EPA and DHA, and it is possibly a temporary storage form for these two fatty acids (Tapiero et al., 2002). Therefore DPA composition is higher than EPA composition. As DHA is the final component of the metabolic pathway, the amount of this fatty acid is the highest when compared to EPA and DPA in all dietary treatments.

Ferrier et al. (1995) fed a control diet, 10 and $20 \%$ flaxseed containing diet and ALA increased 
Table 5

Fatty acid composition of the fish oil and flaxseed oil which were used in modified diets ( $\%$ of total fatty acids)

\begin{tabular}{lcc}
\hline & Flaxseed & Fish oil \\
\hline $14: 0$ & 0.08 & 9.01 \\
$16: 0$ & 6.39 & 20.65 \\
$16: 1$ & 0.11 & 8.90 \\
$18: 0$ & 4.94 & 4.53 \\
$18: 1$ & 16.52 & 17.29 \\
$18: 2(n-6)$ & 14.62 & 1.84 \\
$18: 3(n-3)$ & 56.90 & 2.21 \\
$18: 4(n-3)$ & - & 2.41 \\
$20: 4(n-6)$ & - & 0.57 \\
$20: 5(n-3)$ & - & 9.90 \\
$22: 5(n-3)$ & - & 1.57 \\
$22: 6(n-3)$ & - & 18.78 \\
$n-6 / n-3$ & 0.26 & 0.07 \\
$\sum$ SFA & 11.42 & 34.19 \\
$\sum n-3$ & 56.90 & 34.87 \\
$\sum n-6$ & 14.62 & 2.41 \\
\hline
\end{tabular}

from $28 \mathrm{mg}$ per egg in the control to 261 and 527 $\mathrm{mg}$ respectively, per egg, in the modified eggs. Also the DHA content increased from $51 \mathrm{mg}$ per egg to 81 and $87 \mathrm{mg}$ per egg. Van Elswyk et al. (1992) reported that ALA increased by $75 \%$ and $\mathrm{DHA}$ acid increased by $35 \%$ in modified eggs. Caston and Leeson (1990) reported that the total $n-3$ value of eggs doubled when the dietary flaxseed ratio increased from $10 \%$ to $20 \%$. Caston et al. (1994) also reported that when dietary flaxseed increased $10 \%$ to $20 \%$, the level of ALA in eggs doubled. But Cherian and Sim (1990) did not observe twice the ALA when the flaxseed ratio was increased from $8 \%$ to $16 \%$. Furthermore Yalçın and Unal (2002) reported that the total $n-3$ value of eggs doubled when the feeding period was increased from 18 days to 36 days with $10 \%$ dietary flaxseed. In this study we did not observe such an increase in the total n-3 fatty acids even when dietary flaxseed oil was doubled $(1.5 \%$ to $3 \%$ ) or dietary treatment was doubled (30 days to 60 days).

Alterations in the fatty acid composition of yolk lipids (increase in n-3 fatty acids and decrease in n6 fatty acids) resulted in a large reduction in the $n$ 6: $n-3$ ratio. In this study enrichment with $n-3$ fatty acids is clearly demonstrated with a consequent decrease in $n-6: n-3$ ratio. $n-6: n-3$ ratio decreased in all dietary types. Over two periods the highest reduction in this ratio was shown in diets IV and V. These diet types have the highest total n-3 fatty acid contents over two periods. The same reduction was shown in diets II and III. These diets contained 1.5\% flaxseed oil and fish oil alone. It can be said that an increase in the n-3 fatty acid source or combining the use of this source in a certain amount resulted in a greater reduction of the $n-6: n-3$ ratio.

Jiang et al. (1991) reported that the incorporation of the PUFA into the egg yolk might counteract the cholesterogenic property of the egg. But Ferrier et al. (1995), reported that the laying hen seems particularly resistant to having her yolk cholesterol level changed, and trials attempting to manipulate the yolk cholesterol component by dietary means have not been successful. They also reported that egg yolk cholesterol concentration was not significantly affected by a flaxseed containing diet. Caston and Leeson (1990) reported that flaxseed dietary treatment had no effect on egg cholesterol content. But Lewis et al. 2000 reported the reduction of cholesterol content of PUFA enriched eggs. Hargis et al. (1991), reported that the cholesterol content of the yolk reduced at weeks 12 and 14 by a menhaden oil containing feeding but this reduction was not consistently observed or sustained. Milinsk et al. (2003) reported that no significant differences in cholesterol were found among egg yolks from hens fed with different oilseed containing diets.

No consistent evidence was provided by the present study to support the yolk cholesterol lowering effect of dietary n-3 PUFA except in diet V (Table 6). The decrease in cholesterol found in diet $\mathrm{V}$ could arise because of the crude fibre content of the diet. Diet $\mathrm{V}$ contains the highest crude fibre of all the diets (Table 1) because it contains the highest amount of flaxseed. Flaxseed used in a modified diet contains $8.00 \%$ crude fibre (Table 7 ). Ayerza and Coates (2000) reported that crude fibre influences the cholesterol metabolism of laying hens by decreasing the absorption of cholesterol, shortening intestinal transit time, and increasing fecal sterol excretion. This reduction was not seen in diet III, the $1.5 \%$ flaxseed containing diet, because the crude fibre content of this diet is similar to the other diets (Table 1). However, higher levels of PUFA and lower levels of SFA could decrease the negative effects of high cholesterol intakes (Milinsk et al. 2003).

The results from the current study indicated that the $n-3$ fatty acids are efficiently passed along the human food chain with the practise of using flaxseed and fish oil in feeding poultry. Egg enrichment is possible with n-3 long chain PUFA by using different amounts of flaxseed and fish oil or both of them in hens' diets. This change in enriched eggs may provide an alternative or additional nutrient for the human diet.

\section{BIBLIOGRAPHY}

Anon. 1989. SAS User's Guide: Statistics Edition. SAS Institute Inc. Cary, NL, USA.

Anon. 2005. Istatistiklerle Türkiye 2003. Devlet Istatistik Enstitüsü Matbaası. Ankara.

AOAC. 1990. Official Methods of Analysis. Association of Official Analytical Chemists, Washington, DC.

AOAC. 1993. Official Methods of Analysis. Association of Official Analytical Chemists, Washington, DC.

Ayerza R, Coates W. 2000. Dietary levels of chia: Influence on yolk cholesterol, lipid content and fatty acid composition for two strains of hens. Poult. Sci. 79, 724-739.

Baucells MD, Crespo N, Barroeta AC, Lopez-Ferrer S, Grashorn MA. 2000. Incorporation of different 
polyunsaturated fatty acids into eggs. Poult. Sci. 79, 51-59.

Caston L, Leeson S. 1990. Dietary flax and egg composition. Poult. Sci. 69, 1617-1620.

Caston LJ, Squires EJ, Leeson S. 1994. Hen performance, egg quality and the sensory evaluation of eggs from SCWL hens fed dietary flax. Can. J. Anim. Sci. 74, 347-353.

Cherian G, Sim JS. 1991. Effect of feeding full fat flax and canola seeds to laying hens on the fatty acid composition of eggs, embryos and newly hatched chicks. Poult. Sci. 70, 917- 922.

Daviglus ML, Stamler J, Orencia AJ, Dyer AR, Liu K, Greenland P, Walsh MK, Morris D, Shekelle RB. 1997. Fish consumption and the 30-year risk of fatal myocardial infarction. N. Engl. J. Med. 336, 1046-1053.

Fernandez G. 1995. Effects of calorie restriction and omega-3 fatty acids on autoimmunity and aging. Nut. Rev. 53, S72.

Ferrier KL, Caston JL, Leeson S, Squires J, Weaver J.B, Holub JB. 1995. a-Linolenic acid and docosahexaenoic acid enriched eggs from hens fed flaxseed. Influence on blood lipids and platelet phospholipid fatty acids in human. Am. J. Clin. Nut.62, 81-86.

Hargis PS, Van Elswyk ME, Hargis BM. 1991. Dietary modification of yolk lipid with menhaden oil. Poult. Sci. 70, 874-883.

Hu FB, Stampfer MJ, Manson JAE, Rimm EB, Wolk A, Colditz GA, Hennekens CH, Willett WC. 1999. Dietary intake of a-linolenic acid and risk of fatal ischemic heart disease among women. Am. J. Clin. Nut. 69, 890-897.

Jıang Z, Ahn DU, Sım JS. 1991. Effects of feeding flax and two types of sunflower seeds on fatty acid compositions of yolk lipid classes. Poult. Sci. 70, 2467-2475.

Joseph DJ, Ackman RG. 1992. Capillary column gas chromatographic method for analysis of encapsulated fish oils and fish oils ethyl esters. J. AOAC Int. 75, 488505.

Kinsella JE, Lokesh B, Stone RA. 1990. Dietary n-3 polyunsaturated fatty acids and amelioration of cardiovascular disease. Possible mechanism. Am. J. Clin. Nut. 52, 1-28.

Lewis NM, Jebury S, and Flanagon NL. 2000. Enriched eggs as a source of omega-3 polyunsaturated fatty acids for humans. Poul. Sci. 79, 971- 974.

Li D, Sinclair A, Wilson A, Nokkote S, Kelly F, Abedin L, Mann N, Turner A. 1999. Effect of dietary a-linolenic acid on thrombotic risk factors in vegetarian men. Am. J. Clin. Nut. 69, 872-882.

Milinsk MC, Murakami AE, Gomes STM, Matsushita M, Souza NE. 2003. Fatty acid profile of egg yolk lipids from hens fed diets rich in n-3 fatty acids. Food Chem. 83, 287-292.

Pandalai PK, Pilat MJ, Yamazaki K, Naik H, Pienta KJ. 1996. The effects of omega- 3 and omega- 6 fatty acids on in vitro prostate cancer growth. Anticancer Res. 16, 815-820.

Simopoulos AP. 2000. Human requirement for $n-3$ polyunsaturated fatty acids. Poult. Sci. 79, 961-970.

Tapiero H, Nguyen G, Couvreur P, Tev KD. 2002. Polyunsaturated fatty acids and eicosanoids in human health and pathologies. Biomed. Pharmacother. 56, 215-222.

Van Elswyk ME, Sams AR, Hargis PS. 1992. Composition, functionality and sensory evaluation of eggs from hens fed dietary menhaden oil. J. Food Sci. 57, 342-344.

Yalçın H, Unal MK. 2002. The influence of dietary flax to laying hens on the fatty acid composition of eggs. VII Food Congress of Turkey, 93-97.

Recibido: 23/1/07 Aceptado: 4/7/07 